\title{
光学活性環状 1,2-ジオールの
} 活用と展開

末宗 洋* 麻生真理子

Usage and Development of Optically Active Cyclic 1,2-Diols

Hiroshi Suemune* and Mariko Aso

Optically active diols are one of the useful groups of compounds for asymmetric reaction as a chiral auxiliary or ligand. Among them, cyclic 1,2-diols are characteristic of the restricted conformation. In this review, we wish to report the use of these compounds for the development of asymmetric reactions such as ring transformations based on intramolecular and intermolecular aldol reactions, and carba-spirocyclization, in which cyclic 1,2-diols are added as a chiral source in combination with a Lewis acid. In addition, the synthesis of optically active cyclic diene compounds starting from cyclic 1,2-diols is also discussed.

Key words: cyclic 1,2-diol, asymmetric reaction, ring transformation, Grob fragmentation, acetalization, intramolecular 1,4-addition, spirocyclization, cyclic diene

はじめに

近年の不斉合成の進展には，目をみはるものがある。 その中で, 光学活性ジオールの活用は, 当初キラルアセ タールとしてのジアステレオ選択的不斉導入法から始 まった1)。

本稿では，エチレングリコールとルイス酸の組み合わ せにより炭素一炭素結合の形成と開裂が連続的に生起す る素反応の発見を契機として，我々がこれまで進めてき た光学活性環状 1,2-ジオールを不斉源とする不斉合成 反応開発の取り組みについて紹介する。

1. ルイス酸とジオールの組み合わせによる炭素-炭 素結合の形成と開裂

\section{2 分子内環変換反応とその不斉反応化}

1,6-または 1, 7-ジカルボニル構造を有する環状ケト ンを，エチレングリコールとルイス酸を組み合わせたア セタール化条件で処理することにより，基質の環構造が 開裂し，新たな 5 員環または 6 員環が形成する骨格変換 反応を確立した。本反応は，次に示す多様な骨格変換反 応の実現に展開することができた。その概要をスキーム 1 に示す2)。

a） 5 員環から新たな 5 員環または 6 員環への変換

* 九州大学大学院薬学研究院

* Graduate School of Pharmaceutical Sciences, Kyushu University

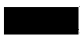

b） 6 員環から新たな 5 員環または 6 員環への変換

c) 5 員環から 7 員環への環拡大

d) ビシクロ [3.3.0]オクタン骨格からビシクロ [3.2.1] オクタン骨格への変換

e) ビシクロ骨格からスピロ骨格への環変換

これらの環変換反応における基本的反応機構は同一で ある。すなわち，分子内アルドール反応，アセタール 化, Grob 開裂が連続的に生起することにより表記の成 績体を与えたものと理解することができる(スキーム 2)。

これらの環変換反応の中で，メソ型化合物を反応基質 とし，エチレングリコールの代わりに光学活性環状 1,2-ジオールを用いることで不斉反応化を試みた。その 結果, スキーム 3 に示寸骨格変換反応に扔いて, 不斉源 として 6 員環 1,2-ジオール $(S, S)-1$ を用いることによ り比較的良好な結果を得ることができた。本知見は，ス キーム 2 の中で，非可逆過程である Grob 開裂における 速度論支配が有効に寄与していることを示唆するもので ある3)。

\section{3 不斉スピロ環化反応}

環変換反応の新様式を開発すべく，新たな基質として エノン 2 を設計し, 常法に従い $\mathrm{BF}_{3} \cdot \mathrm{OEt}_{2}$, エチレング リコールと反応させた。しかし, 予想に反し, 思いがけ ない成績体が得られた。スピロ化合物 3(55\%)と 4 $(16 \%)$ である $($ スキーム 4)。これを契機として開発され たのがスピロ環化反応である。このタイプの反応として は従来, アザスピロ環化反応や酸性条件下でのカチオ 


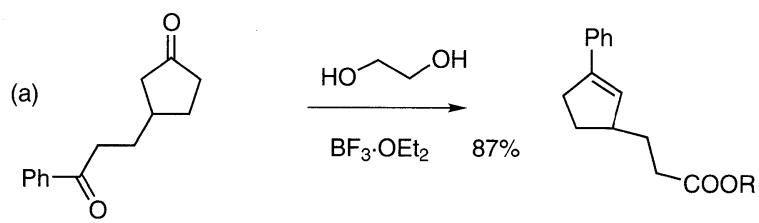

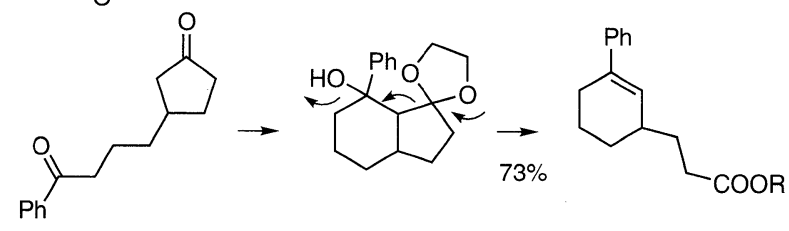

(b)<smiles>CC(=O)CC1CCC(=O)CC1</smiles><smiles>CC(=O)CCC1CCC(=O)CC1</smiles>

Scheme 1 Ring transformations using $\mathrm{BF}_{3} \cdot \mathrm{OEt}_{2}$ and ethylene glycol.

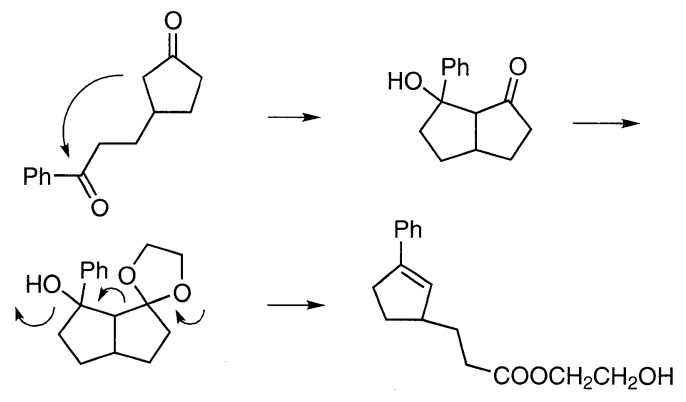

Scheme 2 Proposed reaction mechanisms.
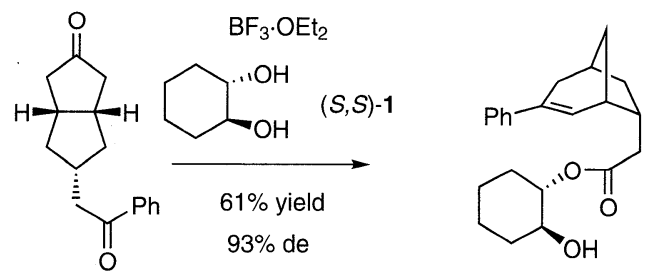

Scheme 3 Asymmetric ring transformation.

ニック $\pi$-環化が知られているのみであった(スキーム $5)^{4)}$ 。本反応はエノール (またはエノレート)が炭素求核 凨としてエノンへ分子内攻撃し，スピロ炭素環骨格を構 築するはじめての例である。

本反応におけるエチレングリコールの役割は，著しい 反応加速である。エチレングリコール存在下では，2 時 間で表記の結果を得たが, $\mathrm{BF}_{3} \cdot \mathrm{OEt}_{2}$ のみの場合では 3 日間の反応で化合物 3(31\%) を得るにとどまった。本反 応は 6 員環形成においては円滑に進行するが，メチレン (c)<smiles>O=C(CCC1CCCC1=O)c1ccccc1</smiles>

(d)

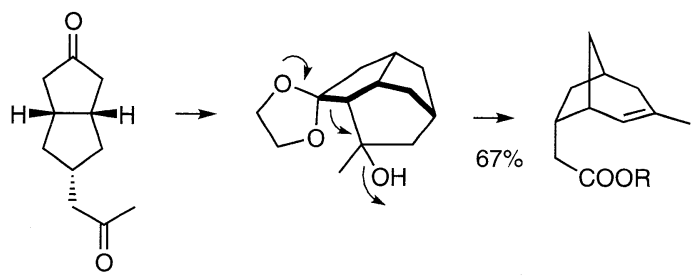

(e)

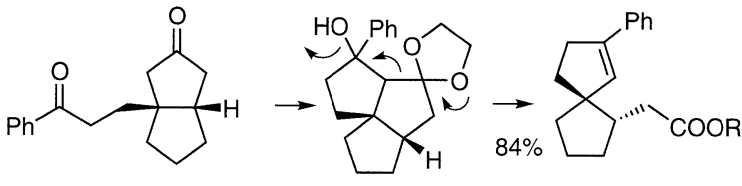

$\mathrm{R}=-\mathrm{CH}_{2} \mathrm{CH}_{2} \mathrm{OH}$

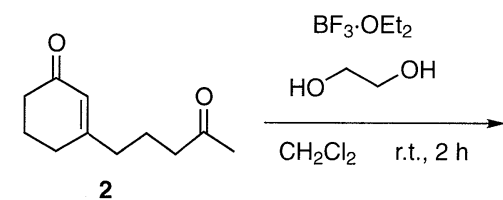<smiles>O=C1CCCC2(CCCC(=O)C2)C1</smiles>

$3(55 \%)$<smiles>CC1(C)COC2(CCCC3(CCCC(=O)C3)C2)C1</smiles>

Scheme 4 Spirocyclization using ethylene glycol.<smiles>NCCCCCC1=CC(=O)CCC1</smiles><smiles>O=C1CCCC2(CCCCN2)C1</smiles><smiles>C=CCCCC1=CC(=O)CCC1</smiles><smiles>O=C1CCCC2(CCCC(OC(F)(F)F)C2)C1</smiles>

Scheme 5 Previous spirocyclization.

炭素鎖が 1 つ少ない基質 5(図 1)の場合 (5 員環形成)で は進行しないことも明らかになった。これは Baldwin 則により理解できる。すなわち，6 員環化では Baldwin 則許容の 6-enolendo-exo-trig 型で進行するのに対し, 5 員環化では Baldwin 則で困難とされている 5-enolendo-exo-trig 型の反応になるからである。これらの知見 
は反応機構考察において重要な因子となった。すなわ ち，エノールエーテルAが中間体として想定された。 この仮説から, エチレングリコールの代わりに光学活性 ジオールを用いることにより, 反応の不斉化が実現でき ると考えた。<smiles>CC(=O)CCC1=CC(=O)CCC1</smiles><smiles>C=C(CCCC1=CC(=O)CCC1)OCCO</smiles>

Fig. 1

そこで，プロキラル基質 2, 6 抒よび 8 に対する光学 活性ジオール共存下での反応を種々検討した。その結 果, 光学活性 6 員環 1,2-ジオール 1 を用いた場合に, 最も良好な不斉収率を得た (スキーム 6$)$ 。成績体 3 小よ び 9 の絶対配置決定は標品を別途合成することにより 行った5)。

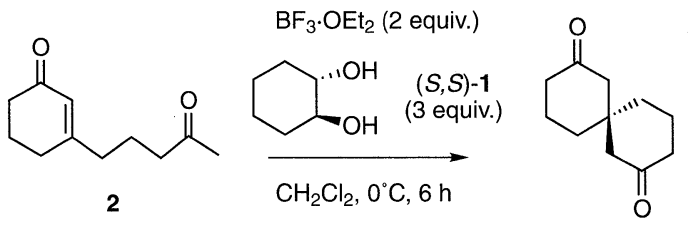

(R)-(-)-3 $86 \%$ yield $85 \%$ ee<smiles>CC(=O)CCCC1=CC(=O)CC(C)(C)C1</smiles>
TMSOTf (2 equiv.) $\frac{(S, S)-1 \text { (3 equiv.) }}{\mathrm{CH}_{2} \mathrm{Cl}_{2} \quad \text { r.t., } 6 \mathrm{~d}}$<smiles>CC1(C)CC(=O)CC2(CCCC(=O)C2)C1</smiles>
$(-)-736 \%$ yield (69\% conv. yield) $91 \%$ ee<smiles>CC(=O)CCCC1=CC(=O)CC1</smiles>
$(R, R)-1$ (3 $\longrightarrow \mathrm{CH}_{2} \mathrm{Cl}_{2}$. r.t. $1.5 \mathrm{~h}$

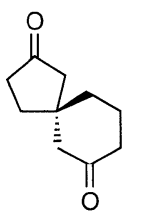

(S)-(-)-9 $72 \%$ yield $63 \%$ ee

Scheme 6 Asymmetric spirocyclization.

さらに，6員環ジオールに扔ける置換基効果を精查す る目的で, $l$-メントールから導いた 4 種の光学活性ジ オール 10a-d の寄与を調べたが，特段の不斉収率の向 上には結びつかなかった(図2，表 1)。

本反応に扮ける不斉誘起を含めた機構については, 次 のように考えている。エノールエーテル中間体としてイ 又型配座 $\mathrm{A} 1$ とボート型配座 A2 が想定できる。2つの $\pi$-系の軌道間相互作用を考慮すると, A 1 が優先するで あろう。本仮定のもとで, キラルエノールエーテルでの<smiles>CC(C)[C@H]1CC[C@@H](C)[C@H](O)[C@H]1O</smiles>

10a<smiles>CC(C)[C@H]1CC[C@@H](C)[C@H](O)[C@H]1O</smiles>

$10 b$

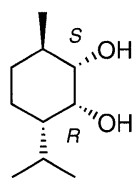

$10 \mathrm{c}$

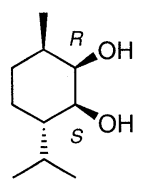

10d
Fig. 2

Table 1 Reaction of 2 with optically active cyclohexane-1,2-diols.

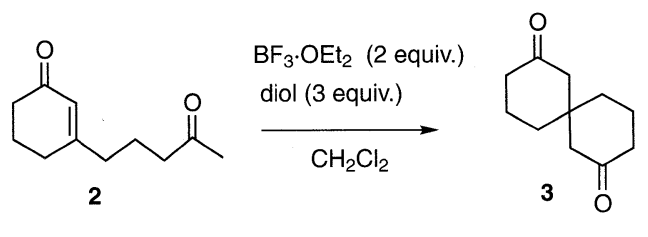

\begin{tabular}{ccccccc} 
entry & diol & temp. & $\begin{array}{c}\text { time } \\
\text { (h) }\end{array}$ & $\begin{array}{c}\text { yield } \\
(\%)\end{array}$ & $\begin{array}{c}\text { Abs. } \\
\text { Config. }\end{array}$ & $\%$ e.e. \\
\hline 1 & 10a & $0^{\circ} \mathrm{C}$ & 12 & 86 & $S$ & 28 \\
2 & 10b & r.t. & 24 & 31 & $R$ & 26 \\
3 & 10c & reflux & 48 & 44 & $S$ & 13 \\
4 & 10d & reflux & 48 & 49 & $S$ & 16 \\
\hline
\end{tabular}

ジアステレオ面選択を考慮すれば，B，Cのような立体 配座が予想される。Cに示した立体障害の影響で，Bか らの反応が優先すると考えることができる。しかし，生 成物として得られたのは，モノアセタール体ではなく， ジケトン体である。1つの考え方として，エノールエー テル形成の際に生じる 1 分子の水が水酸基に配位し， D のような経路からへミアセタール中間体を形成すると考 えることも可能である(図 3)。

また, 成績体 $(-)-7$ を用いた実験結果より, 本反応 では逆反応も生起することが明らかになった。すなわ ち，(-)-7を不斉スピロ環化反応と同一条件で処理す ると，基質の鏡像体過剩率はその反応温度に応じて低下 するとともに，化合物 6 の生成も確認された(スキーム 7)。興味樑いことに, 本逆反心は位置選択的に生起して 打り，もう1つの生成可能なエノン $\mathrm{E}$ は検出されな かっだ)。

本不斉反応の実際の反応機構は未だ不明であり, 上記 の提案は我々の作業仮説とご理解いただきたい。

\section{4 分子内環化: アルドール反応 vs 共役付加}

これまでに示した 2 種の骨格構築反応は, 同一のアセ タール化条件で生起する炭素-炭素結合形成反応, すな わち分子内アルドール反応および共役付加反応に基づく ものである。それでは，これらを支配する因子は何であ ろうか。そのような興味から，化合物 11 を基質として 設計し，その反応選択性について検討した。

基質 11 から予想される環化反応は，1）path A を経 由して共役付加成績体 12 を与えるルート，2）path B 


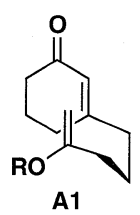

chair conformation

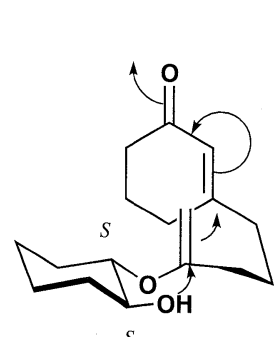

$S$

B

$(R)-(-)-3$

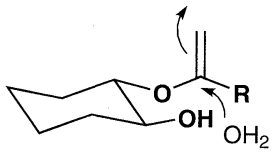

D

Coordination mechanism

Fig. 3 Proposed mechanisms for spirocyclization.
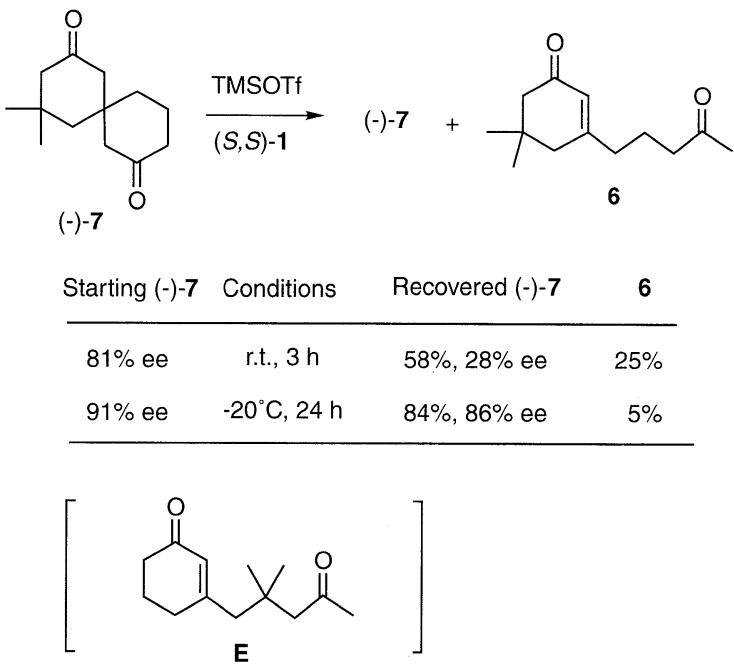

Scheme 7 Evidence for reverse reaction.

を経由してビシクロ[3.3.1]ノナン成績体 13,14 を与え るルート，3）置換基にメチレンを有する $\left(\mathrm{R}=\mathrm{CH}_{2} \mathrm{R}^{\prime}\right)$ 場合にのみ可能な path $\mathrm{C}$ を経由してジエノン成績体 15 を与えるルート，である(スキーム 8)。結果をまとめる と次のようになる(表 2)。

1) 反応ルート選択には置換基 $\mathrm{R}$ の寄与が大きい。基質 11a, 11bでは条件により path A が優先する (entries 1,
4）。しかし，Rがかさ高い 11c，11d では立体障害のた め共役付加は困難となる (entries 5-8)。

2) 基質 $11 \mathrm{c}$ では 2 種のアルドール反応のうち, ジオー ルのない場合には path C が優先するが, ジオール共存 下では path B の寄与も若干増大する (entries 5, 6)。

3) 基質 11d では path B のみを経由した成績体を与え る(entries 7,8)。

4) ジオール共存下では程度の差はあるが，いずれの ルートの場合にも反応加速が見受けられる。

これらの結果より，立体障害を始めとする負の要因が ない場合には, ジオール存在下では分子内共役付加が優 先する傾向が見受けられる7)。それとともに，分子内共 役付加反応抢よびアルドール反応のいずれに执いても, ジオールがエノールエーテル形成という形で関与し, 反 応加速に寄与している可能性を示すものである。

\section{5 分子間環開裂反応と不斉反応 ${ }^{8}$}

本章第 2 項で述べた環変換反応は分子内アルドール反 応に基づくものであった。このことから，最初に $\beta$-ヒ
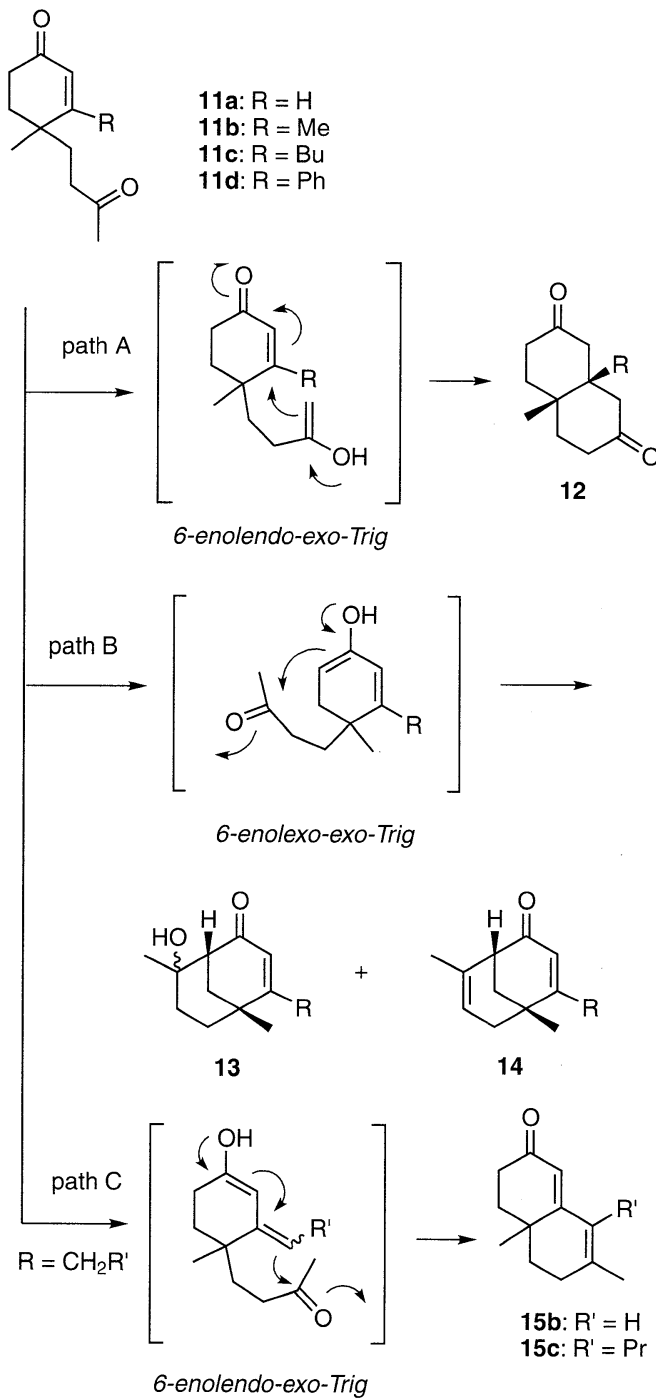

Scheme 8 Possible reaction pathways of 11. 
Table 2 Intramolecular reaction of 11.

$\begin{array}{lllllll} & & & \\ \end{array}$

a) A mixture of 12b, its mono-acetal, and bis-acetal was obtained.

ドロキシケトンが形成されれば，その後の炭素-炭素結 合開裂過程も進行するものと予想された。そこで, 同種 拉よび異種アルドール反応に基づく環開裂反応を検討し た(スキーム 9)。シクロへキサノンを用いた反応では予 想された成績体Fではなく，二重結合の位置異性体 16 を 75\%の収率で得た。一方, ベンズアルデヒドとシク ロペンタノンとの反応では，E-オレフィン体 17(61\%) を得た。

本反応の不斉化を実現すべく, メソ型ビシクロケトン 18，22，25 を基質として光学活性環状ジオール存在下, ベンズアルデヒドとの反応を行った(スキーム 10)。結 果として以下の諸点が挙げられる。<smiles>O=C1CCCCC1</smiles><smiles>CCOCCOCCO</smiles><smiles>O=C(CCCCCC1=CCCCC1)OCCO</smiles>

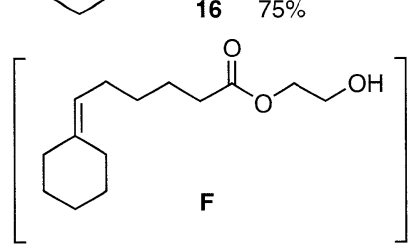

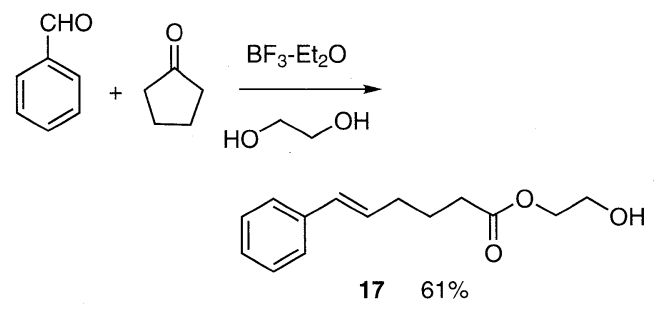

Scheme 9 Ring cleavage based on intermolecular aldol reaction.
1)これらの反応では, 用いるジオールのリングサイズ により化学収率にかなりの差異が見受けられた。すなわ ち，6員環ジオール 1 では，環開裂成績体 19, 23, 26 の 収率は30-46\%であるが，7員環ジオール 20 を用いた 場合では 53-81\%と比較的良好である。

2) 環開裂成績体 19, 23, 26 のジアステレオマー過剩率 (de)は直接には測定せず，エステル交換により対応す るメチルエステル 21, 24, 26 に変換後, キラルカラムを 用いた HPLCにより鏡像体過剩率 (\% ee) を決定した。 その結果，不斉収率には基質の環員数の影響が大きいこ とが判明した。最も良好な結果を与えたのは 22 を基質 とした場合であったが，その不斉収率は $69 \%$ ee にとど まった。また，絶対配置は既知化合物へ誘導することに より決定した。

本不斉誘起反応のメカニズムについては，次のように 䒓えている。ジオール存在下での反応加速効果について は，先のスピロ環化反応と同様である。そこで，本反応 においてもキラルエノールエーテルを経由し，アセター ル形成に引き続く分子間アルドール反応によりジアステ レオマー G, Hが形成されると考えている。ここまでは 可逆過程である。一方，Grob 開裂は非可逆過程である。 G, H に拈ける立体障害の違い(スキーム 11)が寄与して いるものと考えている。

本不斉反応の合成化学的応用を紹介する。基質 22 , $(S, S)$-20 を用いる反応により得た ent-23b $(75 \%, 61 \%$ de）を出発原料とし, 二重結合のオゾン分解と $\mathrm{NaBH}_{4}$ 処理，ついでトリプタミンを用いたアミド形成により 27 へと簡便に導いた。27は (一)-alloyohimbane の合成 中間体であり ${ }^{9)}$ ，その形式合成を達成した（スキー 


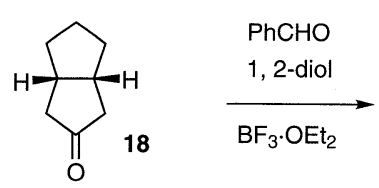

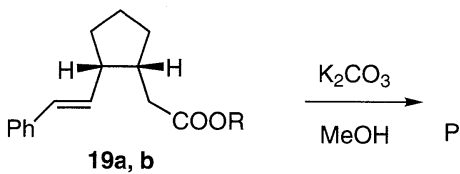

19a, b

$19 \mathrm{a}:(\mathrm{ROH}=(R, R)-1) 34 \%$

19b : $(\mathrm{ROH}=(S, S)-20) 81 \%$

(-)-21 (26\% ee)

$(+)-21(14 \%$ ee $)$

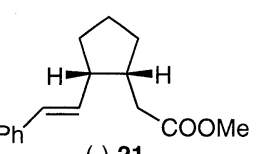

$-21$

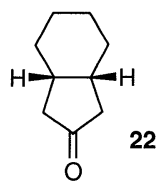

$\mathrm{PhCHO}$

1, 2-diol

$\underset{\text { Lewis acid }}{\longrightarrow}$

$\mathrm{BF}_{3} \cdot \mathrm{OEt}_{2}$

$\mathrm{BF}_{3} \cdot \mathrm{OEt}_{2}$

23a : $(\mathrm{ROH}=(R, R)-1) 30 \%$
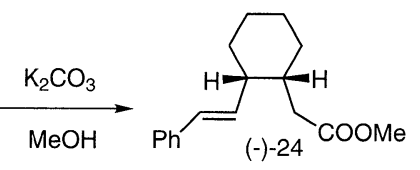

23a,

TMSOTf

23b : $(\mathrm{ROH}=(R, R)-20) 79 \%$

$(-)-24(49 \%$ ee $)$

$(-)-24(60 \%$ ee $)$

$(-)-24(69 \%$ ee $)$
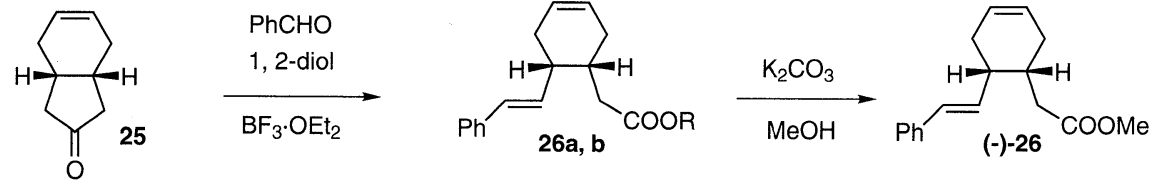

25a : $(\mathrm{ROH}=(S, S)-1) 46 \%$

(+)-26 (51\% ee)

25b : $(\mathrm{ROH}=(R, R)-20) 53 \%$

(-)-26 (53\% ee)

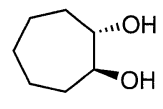

$(S, S)-20$

Scheme 10 Asymmetric reaction using meso-bicyclic substrates.

$22+(R, R)-20+\mathrm{PhCHO}$

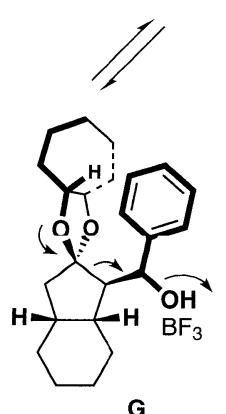

G

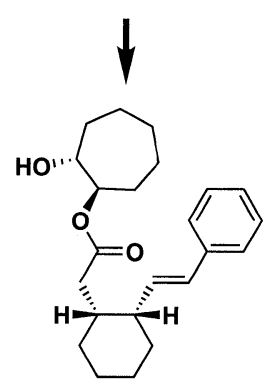

Major product<smiles>C=C=C</smiles>

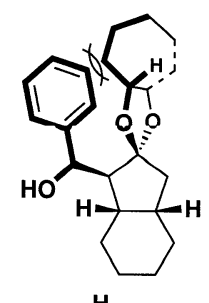

H

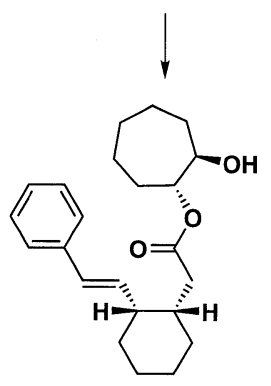

Minor product

Scheme 11 Proposed mechanisms for asymmetric induction.

ム 12)。

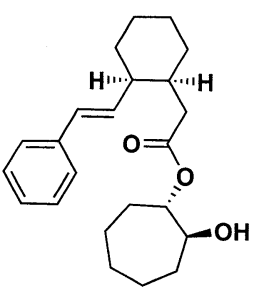

ent-23b $61 \%$ de

1) $\mathrm{O}_{3}$

2) $\mathrm{NaBH}_{4}$

3)<smiles>NCCc1c[nH]c2ccccc12</smiles><smiles>O=C(C[C@H]1CCCCC1(CO)CO)NCCc1c[nH]c2ccccc12</smiles>

Scheme 12 Formal synthesis of (-)-alloyohimbane.

2. 光学活性配位子を指向した環状ジエン化合物の 合成

本章では環状 1,2-ジオールを活用する光学活性環状 ジエン配位子の合成について述べる。

触媒的不斉合成反応に活用されている光学活性配位子 の大多数はリン化合物, アミン，アルコキシド，カルボ キシラート等で占められる。光学活性ジエンを配位子と する金属錯体を合成し，それを触媒とする不斉合成反応 
を開発することは，本研究領域に新たな視点をもたらす ものと考えた。予想される最大の難問は, 光学活性ジエ ンが配位したままで進行し得る素反応の探索および開発 である。このような意味で, 最近報告された林ら ${ }^{10)} の$ 不 斉 1,4-付加反応 (スキーム 13) は画期的なものといえる。

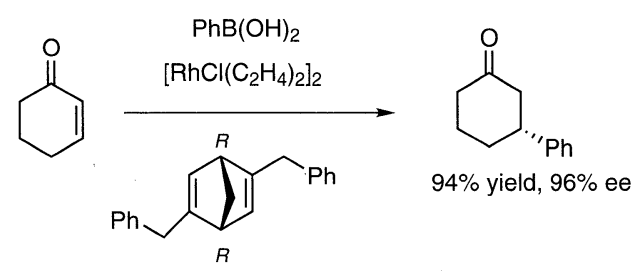

Scheme 13 Hayashi's asymmetric 1,4-addition. ${ }^{10 a)}$

以下に述べる我々のアプローチは，不斉合成反応開発 という目標には未だ至っていないが，現在までの研究の 進展について紹介させていただく。

\section{1 シクロオクタジェン等価体としての光学活性}

9-オキサビシクロ[3.3.1]ノナ-2,6-ジエン

シクロオクタ-1, 5-ジエンはオレフィン性二座配位子 としてパラジウムやロジウム錯体形成に用いられてい る ${ }^{11)}$ 。本節では, シクロオクタジエン等価体としての光 学活性 9-オキサビシクロ [3.3.1] ノナ-2, 6-ジエン 33 の 合成について述べる。

8 員環エンジオール 28 の両鏡像体は, ラセミ体ジア セタートの酵素加水分解における速度論的光学分割によ り容易に調製できる ${ }^{12)} 。 こ の 28$ をヤトニド 29 に変換 後, 低温で臭素を付加させると, 望ましいジアステレオ マー30(89\%) を優先的に得た。ついで, 酸処理すると 脱アセトニド化とともに, 渡環エーテル形成反応が生起

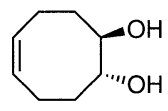

$(-)-28$
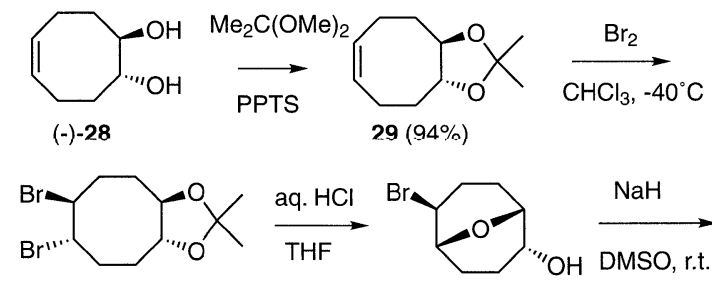

$30(89 \%)$

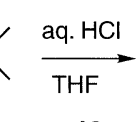
$50^{\circ} \mathrm{C}$
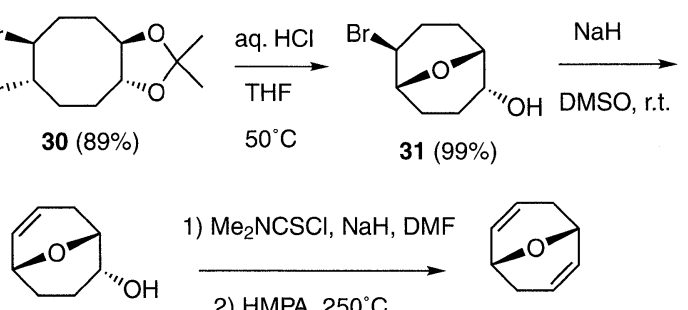

$32(70 \%)$

1) $\mathrm{Me}_{2} \mathrm{NCSCl}, \mathrm{NaH}, \mathrm{DMF}$

2) $\mathrm{HMPA}, 250^{\circ} \mathrm{C}$

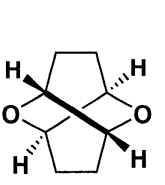

$(-)-34$

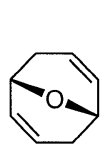

$(S, S)-33$

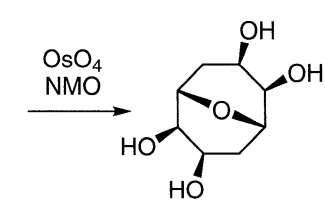

(+)-35 (72\%)
Scheme 14 Synthesis of optically active 33.
し定量的に 31 を与えた。引き続く塩基処理では望みの 脱臭化水素体 $32(70 \%)$ と, 再度のエーテル形成により $D_{2}$ 一対称性を有する光学活性 2, 7-ジオキサツイスタン $34(21 \%)$ を得た。化合物 32 からの脱水反応はチオカル バマートに誘導後，熱処理により行い，2 工程 45\%にて 目的とする 33 に導いた。ついでながら，33のcis-ジヒ ドロキシル化は完璧なジアステレオ選択性を示し，1工 程でテトラオール 35 を単一成績体として与えた(スキー $\Delta 14)^{13)}$ 。

\section{2 光学活性シクロヘキサジェンおよびビシクロ [2.2.2]オクタジエン類の構築 ${ }^{14,16)}$}

光学活性 6 員環エンジオール 36 もまた, 対応するラ セミ体ジアセタートの酵素加水分解を活用する速度論的 光学分割により調製できる。この 36 の二重結合への臭 素付加と脱臭化水素により目的とするジエン体 38, 39 へ容易に導いた。化合物 36 のジアセタートに対する臭 素付加では 2 種類のトランス付加体を与えたが，そのジ アステレオ選択性は極めて低いものであった (33\% de)。 この問題は, ジオール 36 への臭素付加により解決でき た。この場合，単一成績体として $37(95 \%)$ を得た。つ いで水酸基をアセチル保護の後，DBUによる脱臭化水 素を行い, ジエン体 38(74\%) を得た。この化合物 38 よ

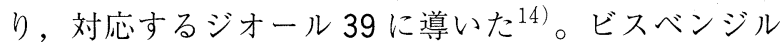
エーテル 40への誘導については, 39 からの直接的変換 は困難であったことから，37 のベンジルエーテル化 (98\%)に引き続く DBU 処理 $(49 \%)$ により達成した(ス キーム 15) ${ }^{15)}$ 。また $(S, S)-39$ のX線結晶解析から判明 したジエン部の二面角は一 $11.5^{\circ}$ であり, 若干のねじれ を持つことも判明した ${ }^{16)}$ 。

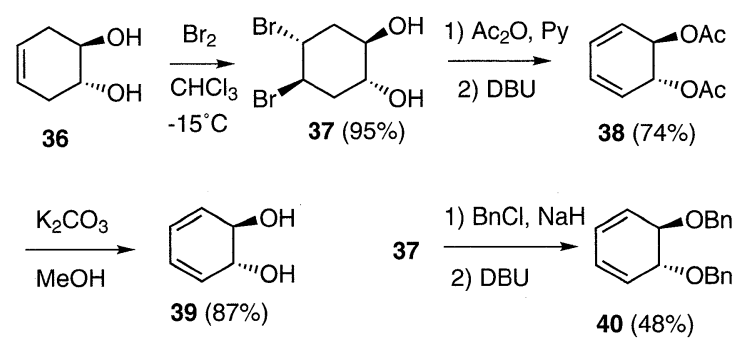

Scheme 15 Synthesis of optically active cyclohexa-1,3dienes.

このようにして得た 38 および 40 を用いて, DielsAlder 反応による光学活性ビシクロ [2.2.2]オクタジエン 系化合物への変換を計画した。スキーム 17 に示す本反 応の立体選択性については, 基質 38,40 が $C_{2}$-対称性を 有することより，ジエン系の面選択性は無視することが できる。両基質とジエノフィル $41 \mathrm{a}$ との反応では高収 率で環化付加成績体 42, 43 を得た。そのうちジアセ タート42を室温下, メタノール中, 炭酸カリウムで処 
理すると，対応するジオールではなく，フタル酸ジメチ ル $(74 \%)$ が得られた。アセタートの加水分解が retroDiels-Alder 反応のスイッチとなる点で，興味深い。

次に $C_{2}$-対称性ビシクロ [2.2.2]オクタ-2,5-ジエン 46 の合成を目的として，40と $41 \mathrm{~b}$ との反応を試みた。こ の場合，exo 選択的ならびに配向選択的に付加成績体 44 (69\%) を単一成績体として得た。化合物 44 よりケトン 体, 次いでヒドラゾンを経由し, 目的とする 46 に変換 できた ${ }^{17) 。 ~}$

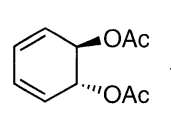

38<smiles>COC(=O)C#CC(=O)OC</smiles>
41a

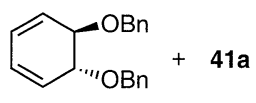

40

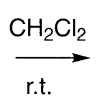<smiles>COCC1C2CC=C(C(=O)OC)C(C2OC)C1OCc1ccccc1</smiles>

$43(90 \%)$<smiles>C=C([18O])Cl</smiles>

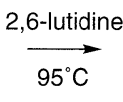<smiles>N#CC1(Cl)C(Br)C2CCC1C(Br)(Br)C2OBr</smiles>

$44(69 \%)$
Scheme 16 Diels-Alder reaction of cyclic dienes.

本章で合成した環状ジエン化合物の不斉配位子として の利用研究については, 現在, 検討を加えているところ である。

\section{おわりに}

以上, 光学活性環状 1,2-ジオールを不斉源とし，ル イス酸との組み合わせにより生起する新たな不斉反応 (スピロ炭素骨格構築反応・分子内および分子間アル ドール反応に引き続く環開裂反応)についてと，新たな 光学活性ジエン系配位子の合成について述べた。後者に ついては, 不斉合成反応への応用展開が今後の大きな課 題であり，また期待でもある。

謝 辞 本研究の一部は文部科学省科学研究費の援助を 受けたものであり，ここに記して感謝します。また，本 研究に精力的に取り組んでいただいた院生・学生諸氏に 謹んで感謝します。

(2005 年 1 月 7 日受理)
文 献

1) 例えば: (a) S. Hatakeyama, K. Sugawara, M. Kawamura, S. Takano, Tetrahedron Lett., 32, 4509 (1991); (b) Y. Kita, H. Maeda, M. Kirihara, Y. Fujii, T. Nakajima, H. Yamamoto, Y. Tamura, H. Fujioka, Chem. Pharm. Bull., 40, 61 (1992); (c) K. Kato, H. Suemune, K. Sakai, Tetrahedron, 50, 3315 (1994); (d) H. Fujioka, H. Kitagawa, N. Matsunaga, Y. Nagatomi, Y. Kita, Tetrahedron Lett., 37, 2245 (1996)

2) 総説: 酒井浄, 有合化, 50, 625 (1992)

3) T. Yamamoto, H. Suemune, K. Sakai, J. Chem. Soc., Chem. Commun., 1992, 1482

4) (a) S. A. Goldeski, D. J. Heacock, J. Org. Chem., 47, 4822 (1982); (b) S. Danishefsky, S. Chackalamannil, B.-J. Uang, ibid., 47, 2231 (1982)

5) S. Yamada, S. Karasawa, Y. Takahashi, M. Aso, H. Suemune, Tetrahedron, 54, 15555 (1998)

6) T. Kiguchi, Y. Tsutusaki, S. Yamada, M. Aso, H. Suemune, Chem. Pharm. Bull., 48, 1536 (2000)

7) S. Yamada, H. Suemune, Chem. Pharm. Bull., 48, 1171 (2000)

8) M. Tanaka, E. Toyofuku, Y. Demizu, O. Yoshida, K. Nakazawa, K. Sakai, H. Suemune, Tetrahedron, 60, 2271 (2004) and references cited therein.

9) M. Isobe, N. Fukami, T. Goto, Chem. Lett., 1985, 71

10) (a) T. Hayashi, K. Ueyama, N. Tokunaga, K. Yoshida, J. Am. Chem. Soc., 125, 11508 (2003); (b) N. Tokunaga, Y. Otomaru, K. Okamoto, K. Ueyama, R. Shintani, T. Hayashi, ibid., 126, $13584(2004)$

11）例えば: (a) A. Miyashita, H. Takaya, K. Toriumi, T. Ito, T. Souchi, R. Noyori, J. Am. Chem. Soc., 102, 7932 (1980); (b) T. Hayashi, A. Katsumura, M. Konishi, M. Kumada, Tetrahedron Lett., 20, 425 (1979)

12) T. Horikawa, M. Tanaka, K. Sakai, H. Suemune, Chem. Pharm. Bull., 46, 17 (1998)

13) A. Takahashi, M. Aso, M. Tanaka, H. Suemune, Tetrahedron, 56, 1999 (2000)

14) H. Suemune, A. Hasegawa, K. Sakai, Tetrahedron: Asymmetry, 6, 55 (1995)

15) A. Watanabe, T. Kamahori, M. Aso, H. Suemune, J. Chem. Soc., Perkin Trans. 1, 2002, 2539

16) J. Gawronski, G. Buczak, A. Katrusiak, P. Skowronek, H. Suemune, Tetrahedron: Asymmetry, 7, 301 (1996)

17) A. Watanabe, M. Aso, H. Suemune, Org. Biomol. Chem.. 1. $1726(2003)$

\section{PROFILE}

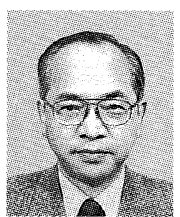

末宗 洋 九州大学大学院薬学研究院・教授 薬学博士

〔経歴〕1975 年九州大学大学院薬学研究科修 士課程修了, 同年昭和大学薬学部助手, 1981 年九州大学薬学部助手, 1995 年同助教授を 経て, 1996 年より九州大学薬学部教授。 1992 年日本薬学会奨励賞受賞。〔専門〕有機 合成化学。[連絡先]e-mail:

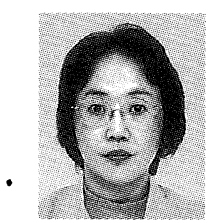

麻生真理子 九州大学大学院薬学研究院・助 手 博士 (薬学)

〔経歴〕 1986 年九州大学大学院薬学研究科修 士課程修了, 1988 年同博士課程中退, 同年 九州大学薬学部教務員を経て同助手。199294 年米国バージニア大学博士研究員。〔尃 門)有機合成化学，核酸関連化学。〔連絡先〕 e-mail: 